\title{
Identification of markers tightly linked to tomato yellow leaf curl disease and root-knot nematode resistance by multiplex PCR
}

\author{
S.X. Chen*, J.N. Du*, L.N. Hao, C.Y. Wang, Q. Chen and Y.X. Chang \\ College of Horticulture, Northwest A \& F University, \\ Key Laboratory of Horticultural Plant Germplasm Resources Utilization in Northwest, \\ Yangling Shaanxi, P.R. China \\ *These authors contributed equally to this study. \\ Corresponding author: S.X. Chen \\ E-mail: shuxiachen@nwsuaf.edu.cn
}

Genet. Mol. Res. 11 (3): 2917-2928 (2012)

Received September 26, 2011

Accepted February 23, 2012

Published July 10, 2012

DOI http://dx.doi.org/10.4238/2012.July.10.4

\begin{abstract}
Seven different commercial $F_{1}$ hybrids and two $F_{2}$ populations were evaluated by multiplex PCR to identify plants that are homozygous or heterozygous for $T y-1$ and $M i$, which confer resistance to tomato yellow leaf curl disease and root-knot nematode, respectively. The Ty-1 and Mi markers were amplified by PCR and identified by digestion of the amplicons with the TaqI enzyme. The hybrids E13 and 288 were found to be Ty/ty heterozygous plants with 398-, 303-, and 95-bp bands, and B08, 314, 198, and A10 were found to be ty/ty homozygous plants with a 398-bp band; whereas 098 did not give any PCR products. The hybrids E13 and 198 were found to be $M i / M i$ homozygous plants with 570 - and 180-bp bands, and 288 and $\mathrm{A} 10$ were found to be $\mathrm{Mi} / \mathrm{mi}$ heterozygous plants, with 750-, 570- and 180-bp bands, and B08, 109 and 314 were found to be $\mathrm{mi} / \mathrm{mi}$ homozygous plants with only a 750 -bp band. We additionally developed a multiplex PCR technique for $J B-1$ and $M i$, which confer resistance to tomato yellow leaf curl disease and root-knot nematode. The $J B-1$ marker identified the genotype of the $T y$ gene, and the plants
\end{abstract}


that produced the 400-bp band were ty/ty homozygous plants, whereas the plants that produced 400- and 500-bp bands were resistant to tomato yellow leaf curl disease. We conclude that multiplex PCRs can be used to reproducibly and efficiently detect these resistance genes.

Key words: Tomato yellow leaf curl disease; $T y-1 ; M i$ gene; CAPS; Marker-assisted selection

\section{INTRODUCTION}

The tomato (Solanum lycopersicon) is an economically important species of the Solanaceae family, and it is cultivated all over the world for human consumption. Recently, tomato crops have often been infected by tomato yellow leaf curl virus (TYLCV), which causes significant yield losses in tomato (S. lycopersicum) crops all over the world (Picó et al., 1996; Pilowsky and Cohen, 2000; Castro et al., 2007). This has occurred since the 1990s in many regions of China including Zhejiang, Shandong, Shanghai, and Guangxi. Many defensive practices were utilized to control the disease after its rapid spread during the first outbreak, but the majority of these defensive methods are not effective. Therefore, breeding for resistance to tomato yellow leaf curl disease (TYLCD) is the most advantageous approach to controlling the damage caused by this viral disease (Castro et al., 2007; Laterrot, 1992), but no resistance has yet been found for the S. lycopersicum germplasm (Hassan et al., 1991; Laterrot, 1995; Ji et al., 2007). Although resistant genes have been detected in wild tomato relatives, a traditional breeding strategy requires a long time for the successful breeding of a new cultivar; therefore, it would benefit selection and gene cloning if a marker closely linked with TYLCV were found.

The resistance to TYLCD in some wild tomato relatives has been controlled by a polygenic recessive pattern (Michelson et al., 1994; Lapidot and Friedmann, 2000), in which Ty-1 was the major gene mapped to the region around markers TG297 and TG97 on chromosome 6 (Zamir et al., 1994; Hanson et al., 2000). The TG97 marker has been used in breeding practice for marker-assisted selection. In addition, another $J B-1$ marker in this region that showed association with the $T y-1$ allele has revealed a polymorphism among the accessions assayed and has been found to be tightly linked to Mi (Castro et al., 2007).

$M i$ is the resistance gene to the main species of the root-knot nematode (Gilbert, 1958). The region on chromosome 6 around markers TG297 and TG97 harbors Mi, Cf-2 and $C f-5$, and $T y-1$ alleles, suggesting that the allele of the $J B-1$ marker is also linked to the $M i$ gene. Although great strides have been made in breeding for resistance to TYLCD, most of the commercial hybrids resistant to TYLCD only contain a single resistance gene. One of the strategies for resistance is to polymerize more than one resistance gene into a single cultivar.

The purpose of this study was to develop multiplex PCRs to identify the genotype for Ty-1 and $M i$ simultaneously. A total of 7 different commercial $\mathrm{F}_{1}$ hybrids were evaluated. Furthermore, the $\mathrm{F}_{2}$ individuals of $\mathrm{E} 13$ and $\mathrm{A} 10$ were screened using multiplex PCR for resistance to TYCLV and Mi. Additionally, a multiplex PCR technique was developed using $J B-1$ and $M i$ conferring resistance to TYCLV and root-knot nematode separately. The results indicated that multiplex PCRs can be used to detect different genes reproducibly and efficiently. 


\section{MATERIAL AND METHODS}

\section{Plant material}

The $\mathrm{F}_{1}$ commercial hybrids used in this study were B08, 109, 314, E13, 198, 288, and A10. Of these hybrids, B08, E13, and 288 are resistant to TYLCD and 109, 314, 198, and A10 are susceptible to TYLCD in the field. Fifteen individuals of each $\mathrm{F}_{1}, 23 \mathrm{~F}_{2}$ individuals of E13, and $19 \mathrm{~F}_{2}$ individuals of A10 were planted at the vegetable research station of the College of Horticulture (P.R. China) in the spring of 2008.

\section{Markers}

Markers employed and primer sequences are listed in Table 1. The primers were synthesized by the Shanghai Shengong Science and Technology Company.

\begin{tabular}{llc}
\multicolumn{2}{c}{ Table 1. Markers of the region used in this research. } \\
\hline Primer & Primer sequences & Restriction enzyme \\
\hline$T y-1$ & CAPS1 F: 5'-TAATCCGTCGTTACCTCTCCTT-3' & TaqI \\
$M i$ & CAPS1 R: 5'-CGGATGACTTCAATAGCAATGA-3' & TaqI \\
$J B-1$ & CAPS2 F: 5'-TCGGAGCCTTGGTCTGAATT-3' & TaqI \\
& CAPS12 R: 5'-GCCAGAGATGATTCGTGAGA-3' & \\
\hline
\end{tabular}

The $T y-1$ and $M i$ primer sequences listed in Table 1 were designed by Michelson et al. (1994). The JB-1 primer sequences listed in Table 1 were designed by Castro et al. (2007).

\section{DNA extraction, single primer PCR, and CAPS}

DNA was extracted from 30-day-old leaves as described by Chen et al. (2006). Briefly, the PCR mixture contained $0.3 \mathrm{U} / \mu \mathrm{L} \mathrm{Taq}$ polymerase, $1.0 \mathrm{mM} \mathrm{Mg}^{2+}, 5 \mathrm{ng} / \mu \mathrm{LDNA}, 0.1 \mathrm{mMdNTP}$, and $0.6 \mu \mathrm{M}$ primer. Amplification for $T y-1$ was carried out in a Mastercycler gradient by denaturation for $5 \mathrm{~min}$ at $95^{\circ} \mathrm{C}$, followed by $1 \mathrm{~min}$ at $94.5^{\circ} \mathrm{C}, 1 \mathrm{~min}$ at $55.5^{\circ} \mathrm{C}$, and $1 \mathrm{~min}$ at $72^{\circ} \mathrm{C}$ for a total of 35 cycles with a final extension step for $10 \mathrm{~min}$ at $72^{\circ} \mathrm{C}$. For $M i$, the optimum conditions for amplification were as follows: $94^{\circ} \mathrm{C}$ for $5 \mathrm{~min}, 35$ cycles of $94^{\circ} \mathrm{C}$ for $1 \mathrm{~min}, 51.5^{\circ} \mathrm{C}$ for $1 \mathrm{~min}$, and $72^{\circ} \mathrm{C}$ for $2 \mathrm{~min}$, followed by an extension step of $10 \mathrm{~min}$ at $72^{\circ} \mathrm{C}$. $\mathrm{JB}-1$ amplification was carried out at $94^{\circ} \mathrm{C}$ for $5 \mathrm{~min}, 35$ cycles of $94^{\circ} \mathrm{C}$ for $1 \mathrm{~min}, 50^{\circ} \mathrm{C}$ for $1 \mathrm{~min}$, and $72^{\circ} \mathrm{C}$ for $2 \mathrm{~min}$, followed by an extension step for $10 \mathrm{~min}$ at $72^{\circ} \mathrm{C}$. After completion of all cycles, $7 \mu \mathrm{L}$ amplified products were digested using TaqI. The digestion reaction consisted of $1 \mathrm{U}$ Taq $\mathrm{I}, 1 \mu \mathrm{L}$ buffer recommended by the supplier and double-distilled water $\left(\mathrm{ddH}_{2} \mathrm{O}\right)$ added to a final volume of $10 \mu \mathrm{L}$. The PCR or digestion products $(10 \mu \mathrm{L})$ were electrophoretically separated on a $2 \%(w / v)$ agarose gel.

\section{Multiplex PCR and digestion}

The multiple PCRs were carried out in a total volume of $20 \mu \mathrm{L}$ containing: $1 \mathrm{X}$ buffer recommended by the supplier, $2.0 \mathrm{mM} \mathrm{MgCl}, 0.1 \mu \mathrm{M}$ of each primer, $0.2 \mathrm{mM}$ dNTPs, $0.04 \mathrm{U}$ Taq polymerase, and $20 \mathrm{ng}$ template DNA, and $\mathrm{ddH}_{2} \mathrm{O}$ was added to bring the total volume to $20 \mu \mathrm{L}$. 
The amplification was carried out in an Eppendorf Mastercycler. For $T y-1$ and $M i$, the optimum conditions for amplification were: $94^{\circ} \mathrm{C}$ for $5 \mathrm{~min}$ and 35 cycles of $94^{\circ} \mathrm{C}$ for $1 \mathrm{~min}, 54^{\circ} \mathrm{C}$ for $1 \mathrm{~min}$, and $72^{\circ} \mathrm{C}$ for $2 \mathrm{~min}$, followed by an extension step for $10 \mathrm{~min}$ at $72^{\circ} \mathrm{C}$. For $J B-1$ and $M i$, the optimum conditions for amplification were as follows: $94^{\circ} \mathrm{C}$ for $5 \mathrm{~min}$ and 35 cycles of $94^{\circ} \mathrm{C}$ for $1 \mathrm{~min}$, $51^{\circ} \mathrm{C}$ for $1 \mathrm{~min}$, and $72^{\circ} \mathrm{C}$ for $2 \mathrm{~min}$, followed by an extension step for $10 \mathrm{~min}$ at $72^{\circ} \mathrm{C}$. Restriction digestions of the amplified products $(7 \mu \mathrm{L})$ were carried out with $10 \mathrm{U}$ of the corresponding enzyme $(1 \mu \mathrm{L})$, and $2 \mu \mathrm{L}$ of the buffer recommended by the supplier, and $\mathrm{ddH}_{2} \mathrm{O}$ added to bring the total volume to $20 \mu \mathrm{L}$. The reactions were performed at $65^{\circ} \mathrm{C}$ for $1.5 \mathrm{~h}$. PCR and digestion products were analyzed by agarose gel electrophoresis ( $2 \%, \mathrm{w} / \mathrm{v}$, agarose in $1 \mathrm{X}$ TAE buffer).

\section{RESULTS}

\section{PCR amplification of $7 \mathrm{~F}_{1}$ hybrids for $T y-1$ and $M i$ gene and digestion of PCR products}

A 750-bp fragment was produced after amplification using Mi primers in $7 \mathrm{~F}_{1}$ hybrids (Figure 1A). The PCR products were distinguishable after cleavage with the TaqI restriction enzyme. E13 and 198 produced 570- and 180-bp bands, indicating that they were $\mathrm{Mi} / \mathrm{Mi}$ homozygous plants; 288 and A10 produced 750-, 570-, and 180-bp bands, indicating that they were $\mathrm{Mi} / \mathrm{mi}$ heterozygous plants; and the 750-bp fragment remained in B08, 109, and 314, indicating that they were $m i / m i$ homozygous plants (Figure 1B).
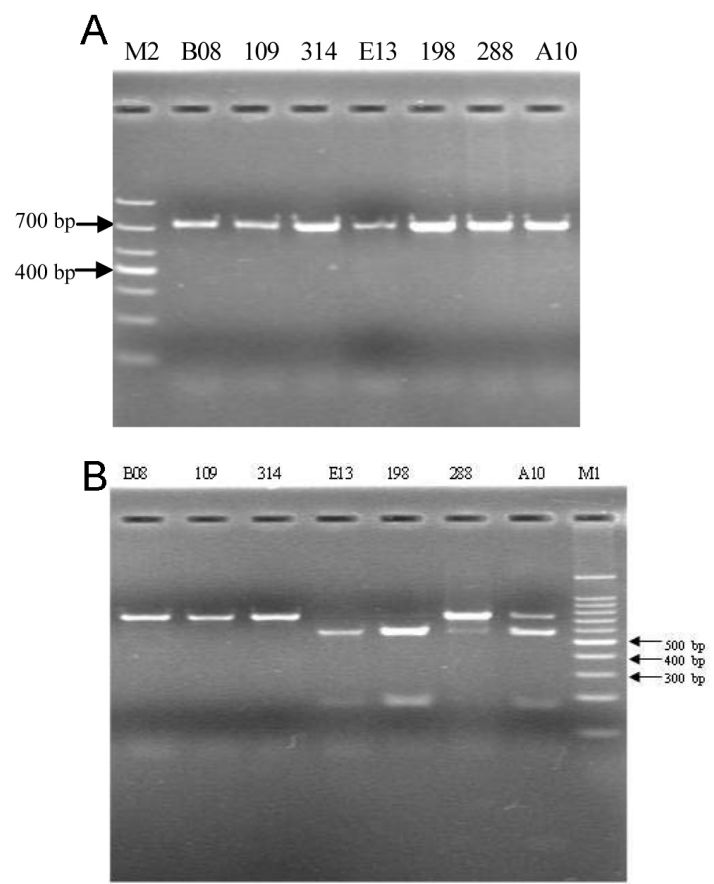

Figure 1. A. PCR profile amplified by the $M i$ primer. Lane $M 2=50$-bp DNA molecular weight marker. B. TaqI digestion of the products amplified by the Mi primer. Lane $M I=100$-bp DNA molecular weight marker. 
A 398-bp band was produced after amplification using $T y-1$ primers in $7 \mathrm{~F}_{1}$ hybrids, with the exception of the hybrid 109 (Figure 2A). The PCR products were distinguishable after cleavage with TaqI. E13 and 288 produced 398-, 303- and 95-bp bands, indicating that they were Ty/ty heterozygous plants; and B08, 314, 198, and A10 produced the full-length 398-bp band without the TaqI digestion site, indicating that they were ty/ty homozygous plants (Figure 2B).

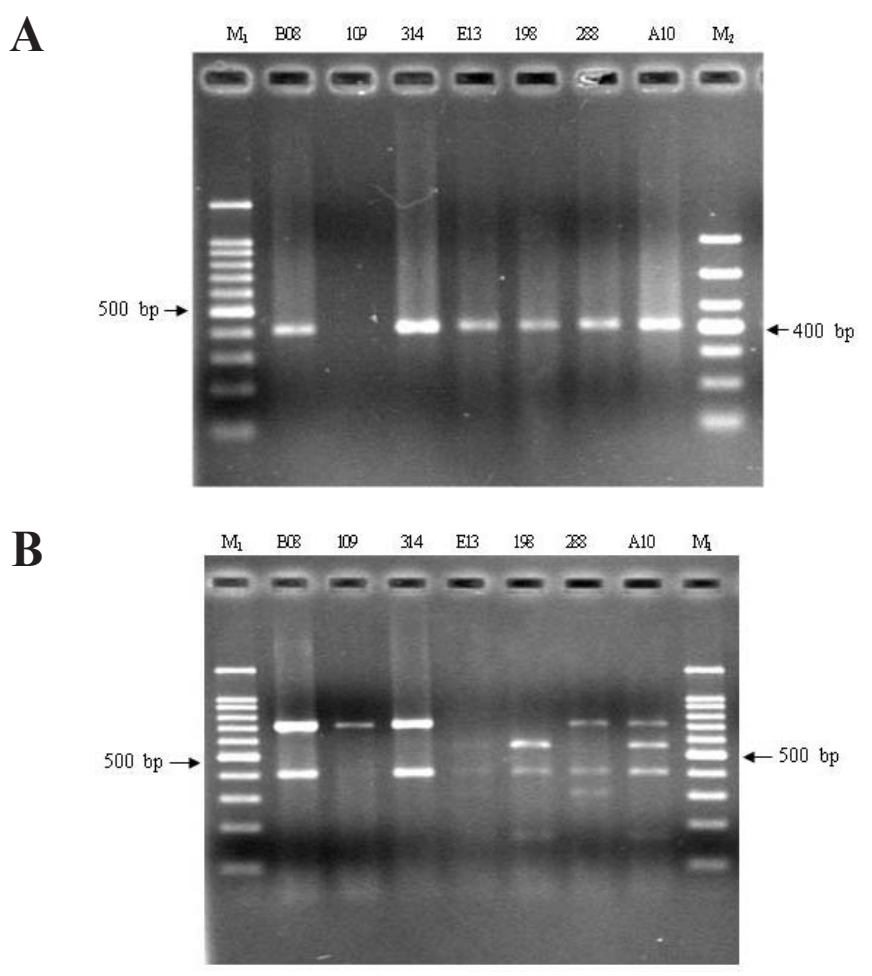

Figure 2. A. PCR profile amplified by the $T y-1$ primer. Lane $M 1=100$-bp DNA molecular weight marker; lane $M 2$ $=50-\mathrm{bp} \mathrm{DNA} \mathrm{molecular} \mathrm{weight} \mathrm{marker.} \mathrm{B.} \mathrm{TaqI} \mathrm{digestion} \mathrm{of} \mathrm{the} \mathrm{products} \mathrm{amplified} \mathrm{by} \mathrm{the} T y-1$ primer. Lane $M 1=$ 100-bp DNA molecular weight marker; lane $M 2=50$-bp DNA molecular weight marker.

\section{Multiplex PCR assays of $M i$ and $T y-1$ and digestion with TaqI}

Multiplex PCR was further developed based on the single primer reaction, showing that multiplex PCR could be used to identify the $M i$ and $T y-1$ genes at the same time. The $M i$ primer produced 750 -bp bands, whereas the $T y-1$ primer produced 398-bp bands (Figure 3A), and the products corresponded to the amplified bands produced by the single $T y-1$ and $M i$ primers. The PCR products were distinguishable after cleavage with TaqI. Both heterozygous plants and homozygous plants produced the original bands, which were produced using the single primer PCR. The results were reproducible after repeated experiments, showing that the multiplex PCR could be used in further experiments to distinguish the different genotypes of the plants (Figure 3B). 
A

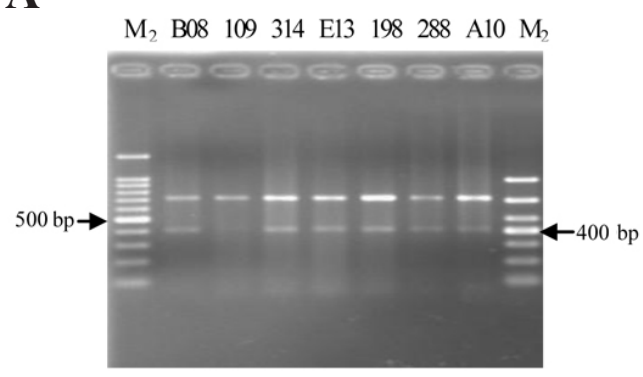

B

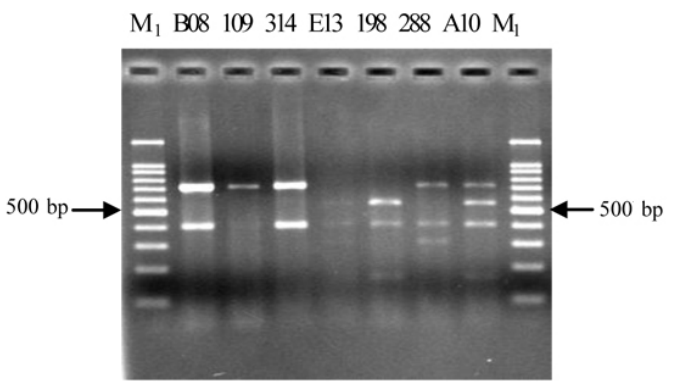

Figure 3. A. Products amplified by $T y-1$ and Mi primers. Lane $M I=100$-bp DNA molecular weight marker; lane $M 2=50-$ bp DNA molecular weight marker. B. Products amplified by the Ty-1 and Mi primers digested by TaqI. Lane $M 1=100$-bp DNA molecular weight marker.

\section{Analysis of $F_{2}$ materials using single PCR and multiplex PCR}

The 750-bp bands were produced after amplification using $M i$ primers in $23 \mathrm{~F}_{2}$ individuals of E13 and $19 \mathrm{~F}_{2}$ individuals of A10. The PCR products were distinguishable after cleavage with TaqI, and 570- and 180-bp bands were produced after cleavage with TaqI in the $23 \mathrm{~F}_{2}$ hybrids of E13. This was consistent with the conclusion that individuals of E13 were $\mathrm{Mi} / \mathrm{Mi}$ homozygous plants (Figure 4A). Bands of 750-, 570- and 180-bp were produced in $\mathrm{F}_{2}$ individuals $1,4,5,6,7,8,9,10,11,13,16$, and 19 of A10, showing that these individuals were $\mathrm{Mi} / \mathrm{mi}$ heterozygous plants. Bands of 570- and 180-bp were produced in $\mathrm{F}_{2}$ individuals $3,15,17$, and 18 of A10, showing that these individuals were $\mathrm{Mi} / \mathrm{Mi}$ homozygous plants; however, individuals 2, 12, and 14 did not have the restriction enzyme digestion site and exhibited the 750-bp fragment, indicating that they were $\mathrm{mi} / \mathrm{mi}$ homozygous plants (Figure 4B).

A 398-bp band was produced after amplification using Ty-1 primers in $19 \mathrm{~F}_{2}$ individuals of E13 and $19 \mathrm{~F}_{2}$ individuals of A10. The PCR products were distinguishable after cleavage with TaqI. Bands of 398- and 303-bp were produced after cleavage with TaqI in $F_{2}$ individuals $1,2,4,7,9,10,11,12,15,16,17,19$, and 23 of E13 (Figure 5A), showing that these individuals were Ty/ty heterozygous plants. Bands of 303- and 95-bp were produced in $\mathrm{F}_{2}$ individuals $3,5,8$, and 18 of A10, showing that these individuals were Ty/Ty homozygous plants. Individuals $6,14,20,21$, and 22 did not have the restriction enzyme digestion site and exhibited the 398-bp fragment, indicating that they were ty/ty homozygous plants (Figure 5A). None of the individuals of A10 had the TaqI restriction site and therefore exhibited the 398-bp fragment, indicating that they were $t y / t y$ homozygous plants (Figure 5B).

These results showed that multiplex PCR could be used to identify the genotype of Mi and $T y-1$ for the $\mathrm{F}_{2}$ individuals at the same time. The products corresponded to the amplified bands produced by single $T y-1$ and $M i$ primers and separate digestion with TaqI. The heterozygous plants or homozygous plants could be identified using this method, and these results were reproducible and reliable. The multiplex PCR could be used to identify the different $M i$ and $T y-1$ genotype of the plants. 
A

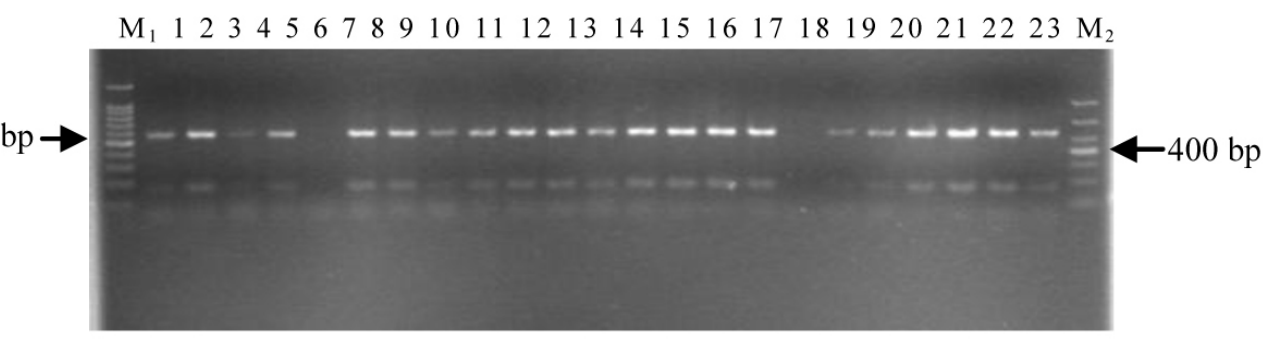

B

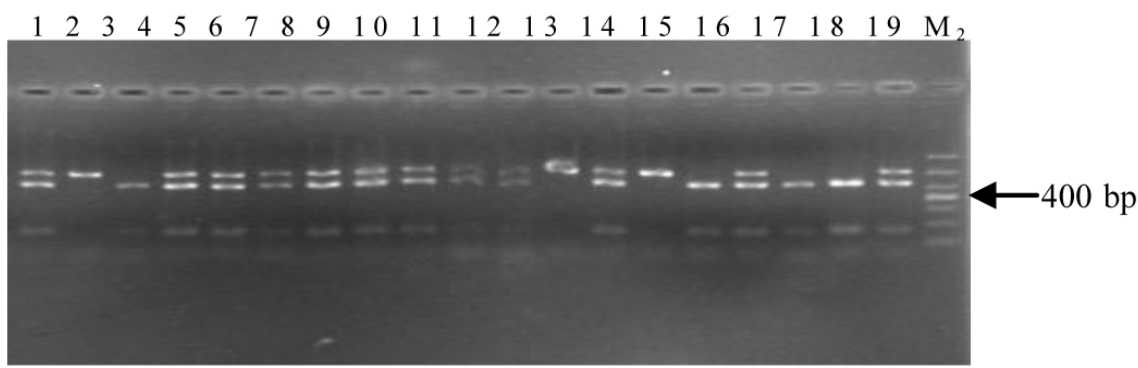

Figure 4. A. CAPS profile of $\mathrm{E}_{13} \mathrm{~F}_{2}$ individuals amplified by the $M i$ primer. Lane $M 1=100$-bp DNA molecular weight marker; lane $M 2=50$-bp DNA molecular weight marker; lanes 1-23= $\mathrm{F}_{2}$ individuals of E13. B. CAPS profile of $\mathrm{A}_{10} \mathrm{~F}_{2}$ individuals amplified by the Mi primer. Lane $\mathrm{M} 2=50$-bp DNA molecular weight marker; lanes $1-19=\mathrm{F}_{2}$ individuals of $\mathrm{A} 10$.

\section{PCR amplification of $7 \mathrm{~F}_{1}$ hybrids for $J B-1$ and $M i$ gene and digestion of PCR products}

PCR amplification of DNA from $\mathrm{F}_{1}$ hybrids and subsequent digestions were carried out using the TaqI enzyme. Bands of 900 bp were obtained for the $J B-1$ marker (Figure 6A). Two different alleles appeared for $J B-1$ after digestion using TaqI, and these alleles consisted of one band slightly larger than $400 \mathrm{bp}$ and a second band of approximately $400 \mathrm{bp}$. This result confirmed a report by Castro et al. (2007), in which the authors proposed that the lines showing these 2 bands had a large introgression from Solanum peruvianum. E13 and 288 had bands of approximately $400 \mathrm{bp}$ and a second slightly larger than $400 \mathrm{bp}$ (Figure 6B). The plants of B08, 109, 314, 198, and A10 had only a single band of approximately $400 \mathrm{bp}$, and they were ty/ty homozygous plants. E13 and 288 were resistant to TYLCD.

PCR was used to identify the $M i$ and $J B-1$ markers simultaneously. The multiplex PCR products of $M i$ and $J B-1$ were distinguishable after cleavage with TaqI. For Mi, E13 and 198 produced 570- and 180-bp bands, indicating that they were $M i / M i$ homozygous plants; 288 and A10 produced 750-, 570- and 180-bp bands, indicating that they were Mi/mi heterozygous plants, and B08, 109, and 314 had a single band of 750-bp, indicating that they were $m i / m i$ homozygous plants (Figure 7A and B).

\section{The analysis of $\mathrm{F}_{2}$ individuals using $J B-1$ and $M i$ multiplex PCR}

This analysis showed that $5 \mathrm{E} 13 \mathrm{~F}_{2}$ individuals $(6,14,20,21$, and 22) produced a 400bp fragment after digestion, which was consistent with results of the $T y-1$ marker in that the 
A $M_{1} 1234567891011121314151617181920212223 M_{2}$

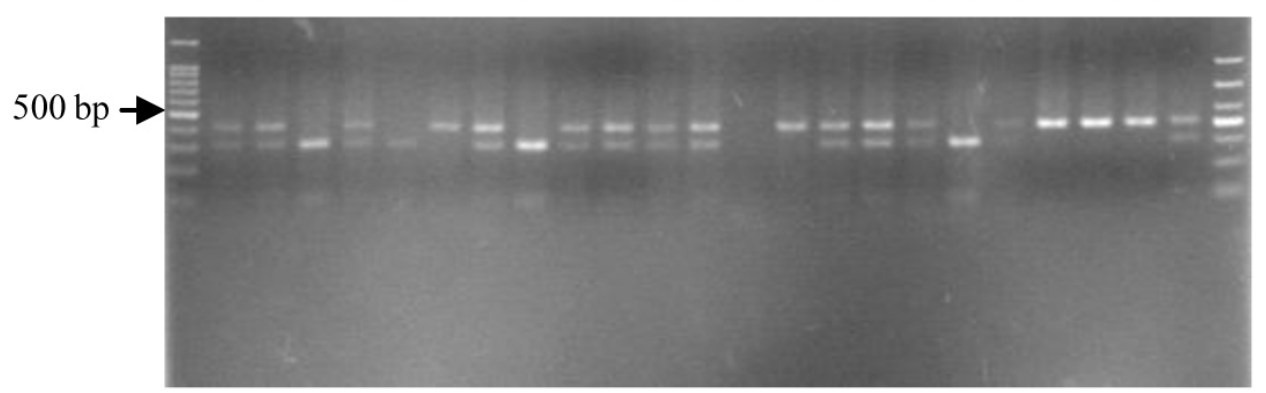

B $\begin{array}{llllllllllllllllllllllll}1 & 2 & 3 & 4 & 5 & 6 & 7 & 8 & 9 & 1 & 0 & 1 & 1 & 12 & 13 & 14 & 15 & 16 & 17 & 18 & 19 & \mathrm{M}_{2}\end{array}$

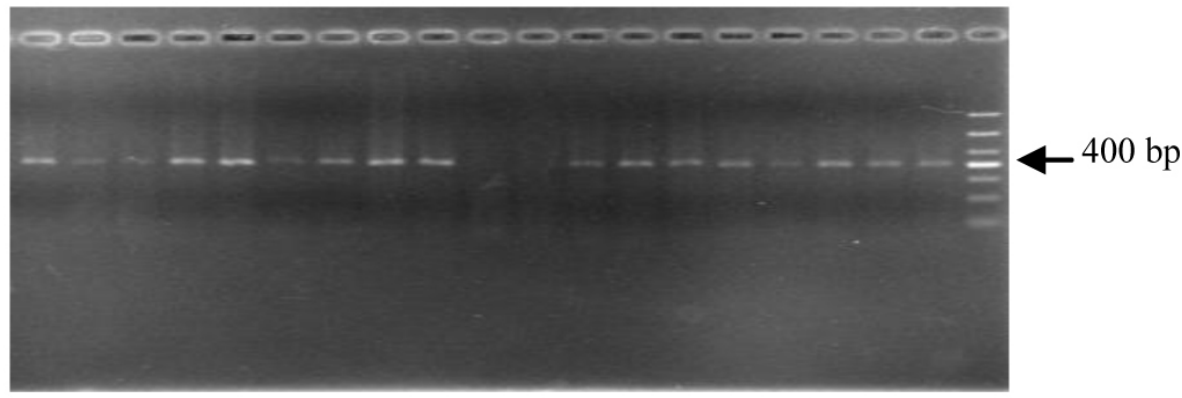

Figure 5. A. CAPS profile of $\mathrm{E}_{13} \mathrm{~F}_{2}$ individuals amplified by the $T y-1$ primer. Lane $M 1=100$-bp DNA molecular weight marker; lane $M 2=50$-bp DNA molecular weight marker; lanes $1-23=\mathrm{F}_{2}$ individuals of E13. B. CAPS profile of $\mathrm{A}_{10} \mathrm{~F}_{2}$ individuals amplified by the $T y-1$ primer. Lane $M 2=50$-bp DNA molecular weight marker; lanes $1-19=\mathrm{F}_{2}$ individuals of A10.

A

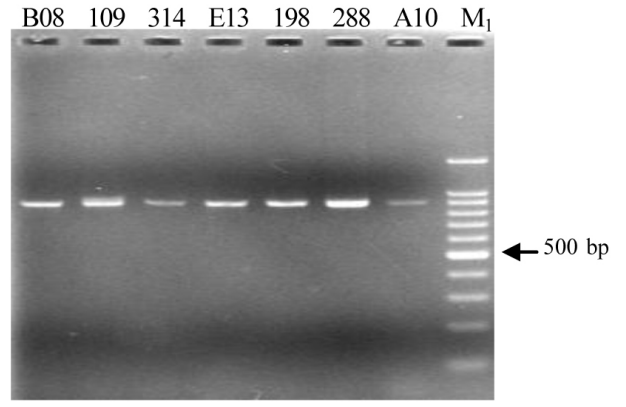

B

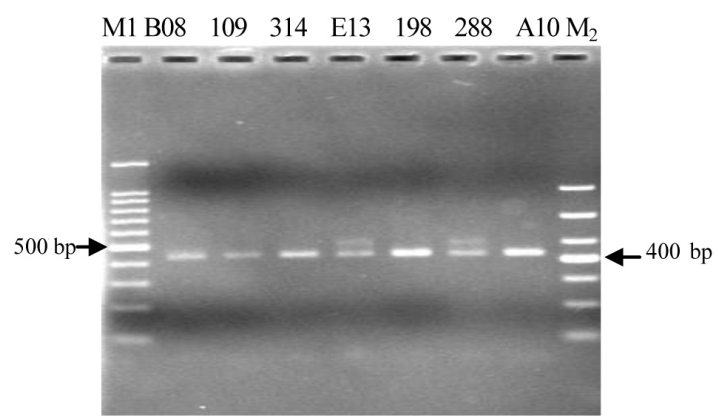

Figure 6. A. PCR profile amplified by the $J B-1$ primer. Lane $M I=100$-bp DNA molecular weight marker. B. TaqI digestion of the products amplified by the $J B-1$ primer. Lane $M 1=100$-bp DNA molecular weight marker; lane $M 2$ $=50$-bp DNA molecular weight marker.

individuals, showing that the 400-bp band produced after digestion in the $J B-1$ marker were ty/ty homozygous plants. Individuals $2,3,4,7,8,9,10,11,12,13,15,16,18,23,24$, and 27 showed 
400- and 500-bp bands (Figure 8A and B). Comparing with the $T y-1$ results in E13 $\mathrm{F}_{2}$ individuals, these individuals were the resistant plants that carry the Ty gene for TYLCD. A10 was a ty/ty homozygous plant, and therefore there was no separation in the $\mathrm{F}_{2}$ individuals at this site.

A

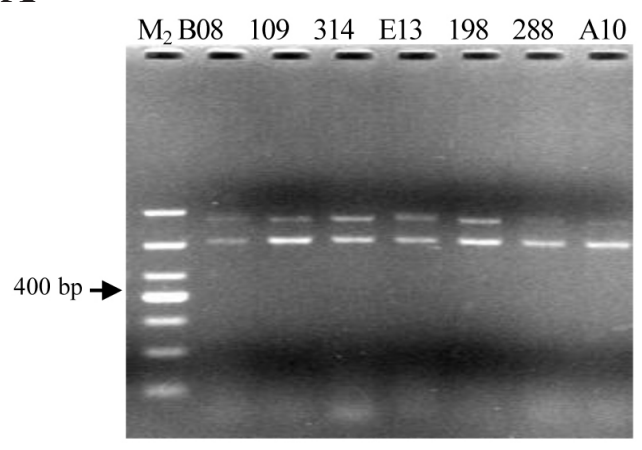

B

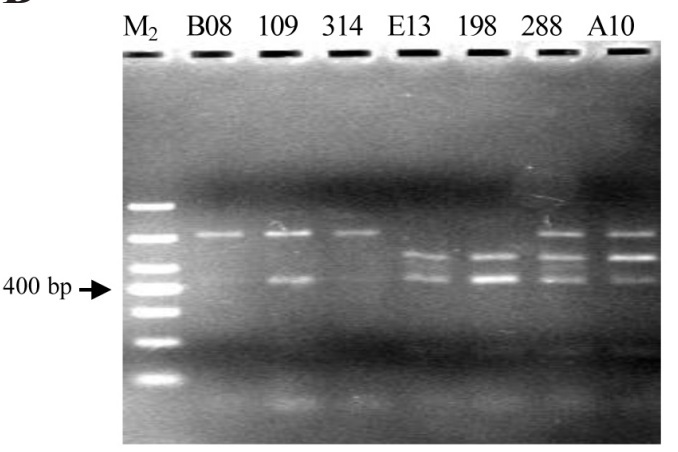

Figure 7. A. PCR profile amplified by the $J B-1$ and $M i$ primers. Lane $M 2=50$-bp DNA molecular weight marker. B. $T a q$ I digestion of the products amplified by $J B-1$ and $M i$ primers. Lane $M 2=50$-bp DNA molecular weight marker.

A $\mathrm{M}_{1} 1234567891011121314151617181920212223 \mathrm{M}_{2}$

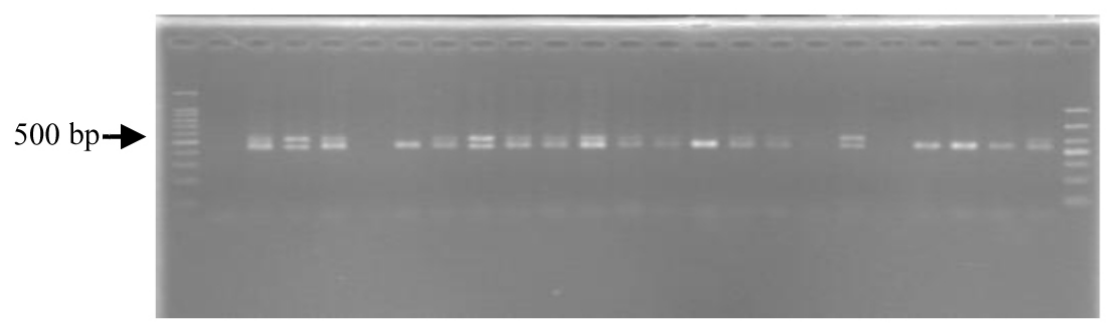

B

$\begin{array}{llllllllllllllllllllllll}1 & 2 & 3 & 4 & 5 & 6 & 7 & 8 & 9 & 1 & 0 & 1 & 1 & 1 & 2 & 13 & 14 & 15 & 16 & 17 & 18 & 19 & \mathrm{M}_{2}\end{array}$

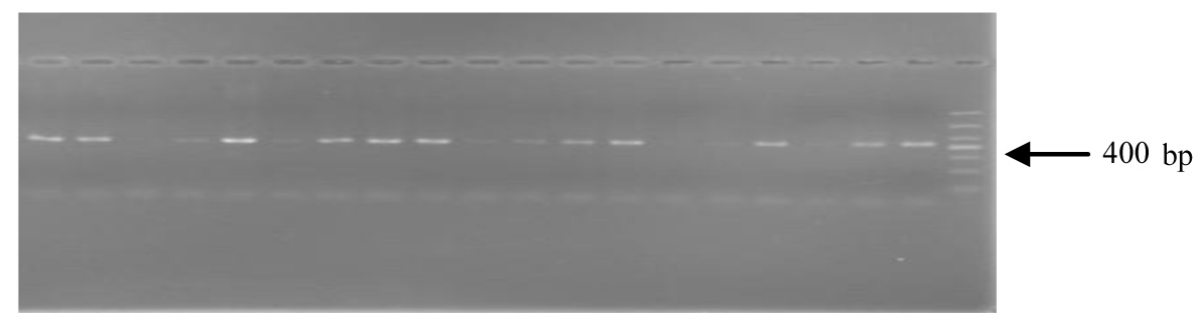

Figure 8. A. $T a q I$ digestion of the products amplified by the $J B-1$ primer. $L a n e ~ M I=100$-bp DNA molecular weight marker; Lane M2 = 50-bp DNA molecular weight marker; lanes 1-23= $\mathrm{F}_{2}$ individuals of E13. B. TaqI digestion of the products amplified by the $J B-1$ primer. Lane $M 2=50$-bp DNA molecular weight marker; lanes 1-19= $\mathrm{F}_{2}$ individuals of E13. 
Therefore, the $J B-1$ marker could identify the Ty genotype, and the individuals that produced the 400-bp band were ty/ty homozygous plants, whereas the plants that produced 400- and 500-bp bands were resistant to TYLCD.

The multiple-PCR strategy was used in the $\mathrm{F}_{2}$ individuals using the $J B-1$ and $M i$ primers. The products digested by the TaqI enzyme corresponded to the single primer restriction fragments of $J B-1$ and $M i$, and showed that these two genes could be simultaneously identified using corresponding PCR primers at the same time (Figure 9A and B).

A $\mathrm{M}_{1} 1234567891011121314151617181920212223 \mathrm{M}_{2}$

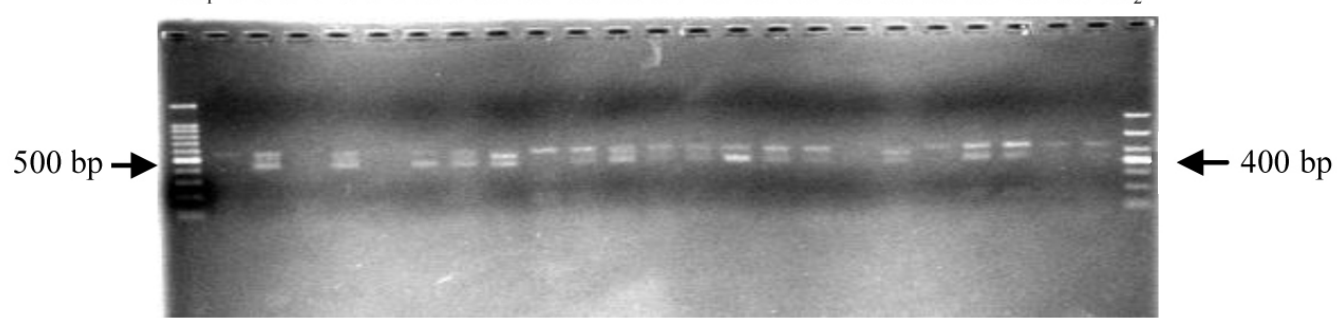

B

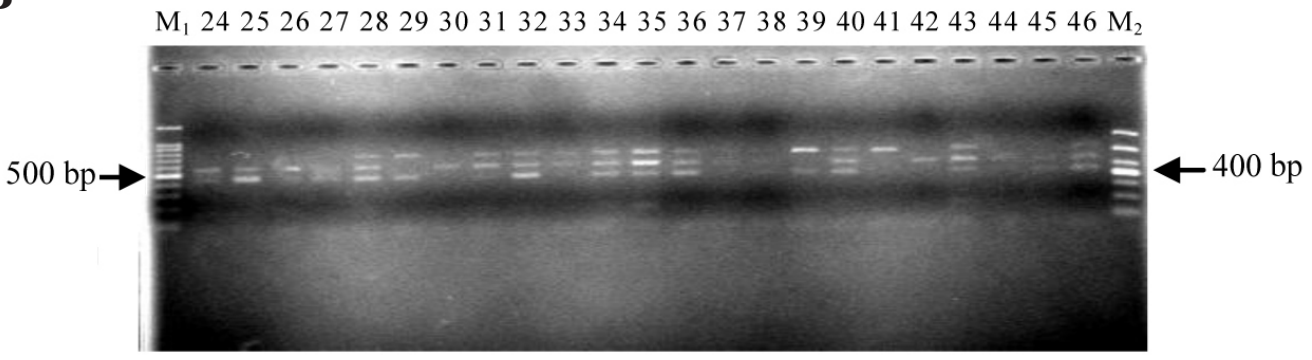

Figure 9. A. TaqI digestion of the products amplified by $J B-1$ and $M i$ primers. Lane $M I=100$-bp DNA molecular weight marker; lane $M 2=50$-bp DNA molecular weight marker; lanes 1-23 = $\mathrm{F}_{2}$ individuals of E13. B. TaqI digestion of the products amplified by $J B-1$ and $M i$ primers. Lane $M 1=100$-bp DNA molecular weight marker; lane $M 2=50$-bp DNA molecular weight marker; lanes 24-27= $\mathrm{F}_{2}$ individuals of E13; lanes 28-46= $\mathrm{F}_{2}$ individuals of A10.

\section{DISCUSSION}

Tomato (Lycopersicon esculentum) is cultivated all over the world as a valuable fruit vegetable but, many crops have recently been threatened by geminiviruses. TYLCV, which belongs to the Begomovirus genus, is mainly transmitted by the whitefly Bemisia tabaci (Fauquet and Stanley, 2003; Fauquet et al., 2003; Kaya and Tanyolac, 2009). The tomato loss due to TYLCV has been overwhelming in most regions of China in recent years. Resistance to TYLCV has not been observed in the S. lycopersicum (Ji and Scott, 2006), so most breeders have to select parent plants from the wild tomato. The resistant gene can be introgressed into cultivated tomatoes from wild tomato relatives by crossbreeding.

It is well-known that resistance to TYLCD is controlled by a major incompletely 
dominant gene, $T y-1$, which is mapped to chromosome 6. The first report of a PCR-based marker for Ty-1 gene was by Milo (2001). Castro et al. (2007) reported a TaqI CAPS marker using primers for $J B-1 F$ and $J B-1 R$, and this marker is tightly linked to $T y-1$. This suggests that this marker could be developed into a useful marker to select for TYLCD resistance.

Yu li et al. (2008) identified the Ty- 1 and $M i$ genes by multiplex PCR in the tomato. Ty- 1 and $M i$ are tightly linked in the tomato with 2 SCAR markers and have been amplified and screened using a single PCR. The PCR products corresponded to the amplified bands produced by a single SCAR primer. These reproducible results proved that these two resistance genes can be simultaneously identified using corresponding PCR primers under adaptable conditions.

In this study, we developed a multiplex PCR using $J B-1$ and Mi primers that are tightly linked to the resistance gene $T y-1$ that can identify resistance to TLYCD and the root-knot nematode at the same time. For the $J B-1$ marker, the individuals that produced 400 -bp bands are the ty/ty homozygous plants and the individuals that produced 2 bands of $400-$ and 500-bp are the resistant genotypes. The multiplex PCR of $J B-1$ and $M i$ will be helpful in breeding tomatoes that are resistant to $T y$ and $M i$.

\section{ACKNOWLEDGMENTS}

Research supported by the Young Core Teacher Foundation of Northwest A \& F University, China (grant \#01140303).

\section{REFERENCES}

Castro AP, Díez MJ and Nuez F (2007). Inheritance of tomato yellow leaf curl virus resistance derived from Solanum pimpinellifolium UPV16991. Plant Dis. 91: 879-885.

Chen S, Fang Y and Yao LF (2006). Quick Preparation for Identification of DNA by PCR. Plant Physiol. Commun. 42: 36-39.

Fauquet CM and Stanley J (2003). Geminivirus classification and nomenclature: progress and problems. Ann. Appl. Biol. 142: 165-189.

Fauquet CM, Bisaro DM, Briddon RW, Brown LK, et al. (2003). Revision of taxonomic criteria for species demarcation in the family Geminiviridae, and an updated list of begomovirus species. Arch. Virol. 148: 405-421.

Gilbert JC (1958). Some linkage studies with the Mi gene for resistance to root-knot. Rep. Tomato Genet. Coop. 8: 15-17.

Hanson PM, Bernacchi D, Green S, Tanksley SD, et al. (2000). Mapping a wild tomato introgression associated with tomato yellow leaf curl virus resistance in a cultivated tomato line. J. Am. Soc. Hortic. Sci. 125: 15-20.

Hassan AA, Wafi MS, Quronfilah NE, Obaji UA, et al. (1991). Screening for tomato yellow leaf curl virus resistance in wild and domestic Lycopersicon accessions. Rep. Tomato Genet. Coop. 41:19-21.

Ji Y and Scott JW (2006). Ty-3, a begomovirus resistance locus linked to Ty-1 on chromosome 6 of tomato. Rep. Tomato Genet. Coop. 56: 22-25.

Ji Y, Schuster DJ and Scott JW (2007). Ty-3, a begomovirus resistance locus near the Tomato yellow leaf curl virus resistance locus Ty-1 on chromosome 6 of tomato. Mol. Breed. 20: 271-284.

Kaya HB and Tanyolaç B (2009). Screening of F3 segregation population lines revealed by Ty-1 markers linked to resistance locus of tomato yellow leaf curl disease (TYLCD) in Tomato (Lycopersicum esculentum). Int. J. Nat. Eng. Sci. 33: 149-153.

Lapidot M and Friedmann M (2000). Breeding for resistance to whitefly-transmitted geminiviruses. Ann. Appl. Biol. 140: 109-127.

Laterrot H (1992). Resistance genitors to Tomato yellow leaf curl virus (TYLCV). Tomato Leaf Curl. Newsl. 1: 2-4.

Laterrot H (1995). Breeding network to create tomato varieties resistant to Tomato yellow leaf curl virus (TYLCV). Fruits 50: 439-444.

Michelson I, Zamir D and Czosnek H (1994). Accumulation and translocation of Tomato yellow leaf curl virus (TYLCV) 
in a Lycopersicon esculentum breeding line containing the L. chilense TYLCV tolerance gene Ty-1. Phytopathology 84: 928-933.

Milo J (2001). The PCR-Based Marker REX-1, Linked to the Gene Mi, can be Used as a Marker to TYLCV Tolerance. Proceedings of Tomato Breeders Round Table, Antigua.

Picó B, Díez MJ and Nuez F (1996). Viral diseases causing the greatest economic losses to the tomato crop. II. The tomato yellow leaf curl virus - a review. Sci. Hortic. 67: 151-196.

Pilowsky M and Cohen S (2000). Screening additional wild tomatoes for resistance to the whitefly-borne tomato yellow leaf curl virus. Acta Physiol. Plant 22: 351-353.

Yu L, Zhu L and Wan Y (2008). Identification of Ty- 1 gene and Mi gene by multiplex PCR reaction in tomato. Mol. Plant Breed. 6: 165-169.

Zamir D, Ekstein-Michelson I, Zakay Y, Navot N, et al. (1994). Mapping and introgression of a Tomato yellow leaf curl virus tolerance gene, Ty-1. Theor. Appl. Genet. 88: 141-146. 